\title{
25. 腹腔鏡検查前後の診断の比較
}

\author{
（釜石市民病院産婦人科） \\ 中 谷一夫
}

（東北大学医学部産科婦人科学教室）

星 合昊

当科でこれ迄に施行した腹腔鏡検查のうち， second look 例を除いた 114 例飞つき，問診，内 診，HSG，超音波断層法などにより得られた検査 前診断と腹腔鏡による診断を比較した．全体とし ての診断の一致率は $53.3 \%$ であった。前診断が 正常であった例の $38.2 \%$ 亿異常が見出され，そ の半数は子宮内膜症であった。しかし，前診断が 子宮内膜症であった例の $1 / 4$ は別の疾患であり， これらは原因不明不妊症診断飞, 或いは子宮内膜
症の治療を行う前に腹腔鏡検査の施行が 望ましい ことを示すものと思われる. $44.7 \%$ の不一致例の 約半数は異常群の中での診断の誤りであり, 特に 子宮内膜症とそれ以外の原因による付属器周囲癒 着との鑑別が困難であることが示された。一方, 愁訴の中に下腹痛を有した 28 例の前後診断の不 一致例 12 例中 5 例は腹腔鏡により内膜症が診断 された例であり，この疾患の前診断の限界が感じ られた。（以上の数字は 2 月 28 日現在） 